\title{
PENURUNAN WARNA DAN TSS LIMBAH CAIR TENUN SARUNG SAMARINDA MENGGUNAKAN KITOSAN DARI LIMBAH CANGKANG KEPITING
}

\author{
DECREASING COLOR AND TSS FROM WASTE WATER OF HOME \\ INDUSTRY WOVEN SARONG SAMARINDA WITH CHITOSAN OF \\ CRAP SHELL WASTE
}

\author{
Sheila Aulia'), Dwi Ermawati Rahayu*2) \\ ${ }^{1,2)}$ Program Studi Teknik Lingkungan, Universitas Mulawarman \\ *Email: dwiermarahayu@ft.unmul.ac.id
}

\begin{abstract}
Abstrak
Industri rumah tangga pembuatan sarung tenun Samarinda menghasilkan limbah cair dengan konsentrasi TSS dan warna yang melebihi baku mutu sehingga memerlukan pengolahan sebelum dibuang ke badan air. Salah satu unit pengolahan yang dapat digunakan adalah unit koagulasi flokulasi dengan menambahkan koagulan. Jenis koagulan yang dapat digunakan salah satunya adalah koagulan dari bahan alam yaitu berasal dari kitosan limbah cangkang kepiting. Tahapan penelitian ini dimulai dengan mempersiapkan koagulan dari kepiting dengan tahapan isolasi kitin yang meliputi tahap demineralisasi, deproteinasi, deasetilasi. Tahap selanjutnya adalah dengan metode jar tes untuk menentukan dosis optimum untuk menurunkan parameter TSS dan warna dari limbah tenun sarung Samarinda. Analisa laboratorium dilakukan terhadap parameter $\mathrm{pH}$, TSS, warna, volume flok yang terbentuk selama jartest. Hasil penelitian dari analisa FTIR menunjukkan bahwa limbah cangkang kepiting mempunyai derajat deasetilasi sebesar 74,25\% yang menunjukkan sebagai kitosan yang mengandung gugus amina dalam rantai karbonnya yang bermuatan positif sehingga dapat berfungsi mendestabilisasi koloid yang bermuatan negatif. Dosis optimum pada pengolahan limbah cair ini dengan menggunakan kitosan $1 \%$ sebesar $35 \mathrm{ml}$ dengan efisiensi removal TSS $88,79 \%$ dan warna $35,49 \%$. Namun terjadi penurunan nilai $\mathrm{pH}$ menjadi 4,98 disebabkan penggunaan asam asetat sebagai pelarut kitosan.
\end{abstract}

Kata kunci: Limbah Sarung Tenun, kitosan, TSS, warna

\begin{abstract}
The Surabaya River's main problem currently was the wastewater resulted from human activities mostly Industrial household manufacturing of Woven Samarinda produce wastewater with concentration of TSS and color that exceeds the quality standards that require treatment. One of the processing unit is coagulation floculation Coagulant type that can be used is the natural coagulant chitosan derived from crab shell waste. First stages of this study : preparing coagulant of crab chitin isolation (demineralization, deproteinasi, deacetylation). The next stage is the jar test method to determine the optimum dose to reduce TSS and color parameters. Laboratory analysis conducted on the parameters $\mathrm{pH}$, TSS, color, volume floc formed during jar test process. The results showed the degree of deacetylation of waste crab shell waste $74.25 \%$ It shows the chitosan-containing amine group in the carbon chain that positively charged so that it can destabilize the negatively charged colloid. The optimum dose using chitosan 1\% is 35ml (TSS removal efficiency of $88.79 \%$ and color removal efficiency 35.49\%). But The increasing of $\mathrm{pH}$ to 4.98 due to the use of acetic acid as the solvent of chitosan.
\end{abstract}

Keywords: wastewater, chitosan, TSS, color 


\section{PENDAHULUAN}

Tenun sarung Samarinda merupakan salah satu produk dari hasil industri tekstil khas Kalimantan Timur yang masih menggunakan cara manual berupa Alat Tenun Bukan Mesin (ATBM). Sebelum proses penenunan benang menjadi kain sarung, ada beberapa tahapan proses yang dilakukan pada benang sebagai bahan baku yaitu proses pembersihan benang sebelum diberi pewarna, pewarnaan benang, proses pencucian benang setelah diberi pewarna, pengkanjian dan penjemuran benang. Tahapan proses dalam pembuatan tenun sarung Samarinda tersebut terutama pada proses persiapan bahan baku akan menghasilkan limbah cair sebagai pencemar di perairan karena menggunakan berbagai macam bahan kimia seperti bahan pewarna. Bahan tersebut merupakan sumber pencemar utama karena hanya sebagian kecil yang terserap pada produk tekstil, sedangkan sebagian besar terbuang bersama air buangan (limbah cair) (Prayudi, 2000). Pengolahan limbah tekstil pada umumnya menggunakan kombinasi dari proses kimia dan fisik dengan proses koagulasiflokulasi dan sedimentasi (Prayudi dan Susanto, 2000). Metode pengolahan koagulasi-flokulasi yang dikombinasikan dengan sedimentasi merupakan metode yang sudah lama digunakan baik pada limbah cair maupun air baku. Penggunaan koagulan kimia telah banyak digunakan dalam proses pengolahan air, seperti alum dan $P A C$. Keterbatasan penggunaan koagulan kimia ini menghasilkan lumpur/ endapan yang masih mempunyai unsur kimia yang dapat membahayakan lingkungan bila dibuang langsung (Hendriarianti dan Suhastri, 2011). Karena keterbatasan koagulan kimia ini, muncul alternatif penggunaan koagulan biologi yang berasal dari limbah industri pangan hasil laut, seperti limbah kulit udang, cangkang kepiting, kulit kerang dan limbah industri pangan hasil laut lainnya berupa hewan bercangkang.

Sebelum digunakan sebagai koagulan terlebih dahulu limbah industri pangan hasil laut tersebut harus melalui beberapa tahapan proses untuk mengisolasi kitin yang ada dan kemudian di proses lagi hingga menjadi kitosan. Kitosan ini merupakan salah satu bahan yang dapat digunakan untuk proses pengolahan limbah cair sebagai koagulan.

Penelitian tentang pengolahan limbah cair industri dengan menggunakan limbah industri pangan hasil laut telah banyak dilakukan. Menurut Harahap (2011), kitosan dari kulit udang mampu menurunkan kadar TSS hingga $71,21 \%$ dan seiring penurunan kadar TSS tersebut parameter kualitas air lainnya turut mengalami penurunan seperti fenol, $\mathrm{BOD}_{5}, \mathrm{COD}$ dan $\mathrm{pH}$ pada limbah cair industri plywood hingga mencapai nilai dibawah baku mutu yang telah ditetapkan. Hasil penelitian Arifin, dkk., (2012), menunjukkan bahwa kitosan dari limbah udang delta mahakam mampu menurunkan kadar warna dari zat warna benang sarung samarinda hingga mencapai 63,10\%. Penelitian lainnya, Prayudi dan Susanto (2000), memperlihatkan bahwa kitosan dari kulit udang mempunyai potensi yang cukup baik sebagai bahan koagulan untuk limbah cair industri tekstil (setelah dilakukan pengenceran), karena dapat menurunkan kandungan beberapa parameter seperti COD, BOD5, kekeruhan dan TSS hingga mendekati nilai penurunan parameter yang sama dengan menggunakan koagulan $\mathrm{FeSO}_{4}$. Menurut data hasil analisa yang telah didapat dan beberapa hasil penelitian yang telah ada, maka melalui penelitian ini akan dilakukan upaya untuk dapat menangani parameter TSS dan warna pada limbah cair tenun sarung Samarinda sebelum akhirnya dibuang ke badan air yaitu dengan menggunakan limbah cangkang kepiting sebagai koagulan.

\section{Tujuan Penelitian}

a. Mengetahui karakteristik kitosan dari limbah cangkang kepiting yang dibuat dan kemampuannya sebagai koagulan dalam penanganan limbah cair tenun sarung Samarinda.

b. Untuk mengetahui dosis optimum dan efisiensi koagulan kitosan dari limbah cangkang kepiting dalam penanganan limbah cair tenun sarung Samarinda dengan parameter TSS dan warna. 


\section{METODA}

Penelitian dilakukan di Laboratorium Kimia Analitik, Anorganik dan Fisik Fakultas MIPA, Laboratorium Kimia Organik Fakultas MIPA dan Laboratorium Rekayasa Lingkungan Fakultas Teknik Universitas Mulawarman sedangkan analisa Fourier Transform Infra Red (FTIR) oleh Laboratorium Kimia Analitik ITB. Limbah cair dari proses pembuatan tenun sarung Samarinda berasal dari industri rumah tangga di Jalan Pangeran Bendahara Kampung Tenun RT. 02 Kelurahan Masjid, Samarinda Seberang, Kalimantan Timur. Tahapan penelitian ini sebagai berikut:

\section{Pembuatan koagulan kitosan}

Tahapan ini diawali dengan persiapan cangkang kepiting yang diambil dari limbah restoran seafood direbus kemudian dicuci dengan air hingga bersih dan dibilas dengan aquades lalu dikeringkan dalam oven pada suhu $110-120{ }^{\circ} \mathrm{C}$ selama 1 jam. Setelah kering kemudian dihaluskan dan diayak dengan ukuran $<100$ mesh. Kemudian dilakukan isolasi kitin dengan tahapan berikut ini:

\section{Tahap Demineralisasi}

Sebanyak 75 g serbuk cangkang kepiting ditambahkan larutan $\mathrm{HCl} \quad 1 \quad \mathrm{~N}$ dengan perbandingan 1:10 (b/v). Campuran dipanaskan selama 4 jam pada suhu $70-80{ }^{\circ} \mathrm{C}$ sambil dilakukan pengadukan pada kecepatan $50 \mathrm{rpm}$ kemudian disaring. Padatan yang diperoleh dicuci dengan aquades hingga $\mathrm{pH}$ netral kemudian dikeringkan di dalam oven pada suhu $70{ }^{\circ} \mathrm{C}$ selama 24 jam dan kemudian didinginkan dalam desikator. Kemudian ditimbang residu kering bebas mineral (Puspawati, dkk., 2010; Pasaribu, 2010).

\section{Tahap Deproteinasi}

Produk hasil demineralisasi kemudian ditambahkan dengan larutan $\mathrm{NaOH} 3,5 \%$ dengan perbandingan 1:10 (b/v). Campuran dipanaskan selama 4 jam pada suhu $65-70{ }^{\circ} \mathrm{C}$ sambil diaduk pada kecepatan $50 \mathrm{rpm}$ kemudian disaring.
Padatan yang diperoleh dicuci dengan aquades hingga $\mathrm{pH}$ netral kemudian dikeringkan di dalam oven pada suhu $80{ }^{\circ} \mathrm{C}$ selama 24 jam dan kemudian didinginkan dalam desikator. Kemudian ditimbang berat kitin yang diperoleh.

\section{Deasetilasi Kitin Menjadi Kitosan}

Kitin dari proses deproteinasi yang telah kering direaksikan dengan larutan $\mathrm{NaOH} 60 \%$ dengan perbandingan 1:20 (b/v). Campuran diaduk dan dipanaskan pada suhu $120{ }^{\circ} \mathrm{C}$ selama 4 jam pada kecepatan $100 \mathrm{rpm}$. Setelah reaksi selesai, campuran didinginkan, disaring, dicuci dengan aquades hingga $\mathrm{pH}$ netral dan dikeringkan dalam oven dengan suhu $80{ }^{\circ} \mathrm{C}$ selama 24 jam. Ditimbang kitosan yang diperoleh. Produk kitosan yang diperoleh diuji kelarutannya dalam larutan $\mathrm{CH}_{3} \mathrm{COOH} 2 \%$ (Puspawati, dkk., 2010).

\section{Analisa karakteristik kitosan}

Analisa karakteristik produk kitosan menggunakan spektrofotometer Fourier Transform Infra Red (FTIR) dengan mengirimkan sampel ke laboratorium kimia analitik FMIPA ITB.

\section{Percobaan jar tes}

Pemeriksaan $\mathrm{pH}$ sampel limbah cair dan dilakukan penyesuaian $\mathrm{pH}$ dengan penambahan larutan $\mathrm{CaCO}_{3}$ (kapur) dengan kadar $2 \%$. Disiapkan 12 buah gelas beker masing-masing diisi sampel limbah cair sebanyak 1 liter, kemudian diletakkan pada alat jar-test serta memasukkan pengaduk kedalam gelas beaker yang berisi sampel limbah cair. Larutan koagulan (larutan kitosan) digunakan dengan dengan kadar 1\%. Dengan variasi dosis yakni $5 \mathrm{ml}$ hingga 60 $\mathrm{ml}$ dengan interval dosis $5 \mathrm{ml}$. Pengadukan dengan menggunakan alat jar-test pada putaran kecepatan 100 rpm selama 3 menit, kemudian kecepatan pengadukan pada alat jar-test diturunkan secara bertahap hingga $40 \mathrm{rpm}$ selama 12 menit. Setelah pengadukan kemudian didiamkan dan dilakukan pengamatan pada flok yang terbentuk. 


\section{Uji kualitas limbah}

Karakteristik limbah cair tenun sarung Samarinda di uji laboratorium sesuai dengan standar SNI 06-6989.3-2004 dengan metode gravimetri untuk parameter TSS dan SNI 6989.80:2011 secara spektrofotometri untuk parameter warna dan $\mathrm{pH}$ mengacu pada SNI 066989.11-2004 dengan menggunakan alat $\mathrm{pH}$ meter.

\section{HASIL DAN PEMBAHASAN}

\section{Isolasi Kitin}

Proses isolasi kitin dari cangkang kepiting dilakukan dalam 2 tahapan, yaitu tahap demineralisasi dan deproteinasi. Tujuan dari proses demineralisasi adalah untuk menghilangkan mineral-mineral yang ada pada cangkang kepiting. Tahap deproteinasi bertujuan untuk menghilangkan protein yang terkandung dalam cangkang kepiting. Kitin dalam cangkang kepiting diperoleh dengan pemurnian yang diawali dengan proses demineralisasi. Pada proses ini digunakan cangkang kepiting yang dihaluskan hingga menjadi serbuk dengan berat 75 gram yang kemudian dilakukan penambahan $\mathrm{HCl} 1 \mathrm{~N}$ dengan tujuan untuk menghilangkan mineral yang terkandung dalam sampel. Pada proses ini terbentuk gelembung-gelembung $\mathrm{CO}_{2}$ yang merupakan indikator terjadinya reaksi antara $\mathrm{HCl}$ dengan garam mineral dengan melarutkan kalsium sebagai kalsium klorida yang larut dalam air.

Rendemen yang dihasilkan dari proses ini adalah $39,56 \%$ atau berat kitin setelah demineralisasi sebanyak 29,67 gr. Hasil dari tahapan demineraslisasi akan dilanjutkan pada tahap deproteinasi yang merupakan tahapan untuk menghilangkan protein yang terkandung dalam cangkang kepiting dengan mereaksikan kitin demineralisasi dengan larutan $\mathrm{NaOH} 3,5 \%$ sehingga protein diekstraksi sebagai natrium proteinat yang larut. Rendemen yang dihasilkan pada tahapan proses ini adalah 93,63\% dari kitin demineralisasi sebanyak 27,78 gr. Jika dibandingkan dari berat cangkang kepiting awal maka rendemen dari proses deproteinasi sebesar $37,04 \%$.

\section{Deasetilasi Kitin Menjadi Kitosan}

Kitin yang diperoleh dari tahapan demineralisasi dan deproteinasi digunakan untuk membuat kitosan melalui reaksi deasetilasi yaitu dengan mereaksikannya menggunakan $\mathrm{NaOH} 60 \%$ pada suhu $120{ }^{\circ} \mathrm{C}$ selama 4 jam pada kecepatan 100 rpm. Selain dengan cara yang conventional tersebut, proses deasetilasi ini dapat dilakukan juga dengan iradiasi microwave dengan waktu yang lebih singkat yaitu 10 menit (Samar, M.M., 2012). Tujuannya adalah untuk menghilangkan gugus asetil yang ada pada kitin. Deasetilasi adalah proses pengubahan gugus asetil menjadi gugus amina. Pada proses ini digunakan suhu $120{ }^{\circ} \mathrm{C}$ agar mengkondisikan reaksi deasetilasi (penghilangan gugus asetil) berjalan optimum dimana semakin tinggi konsentrasi $\mathrm{NaOH}$ yang digunakan maka semakin cepat waktu reaksi sehingga berat molekul kitosan yang diperoleh semakin besar (Srijianto, dkk., 2006). Kemudian residu dicuci dengan aquades hingga $\mathrm{pH}$ netral untuk menghilangkan $\mathrm{NaOH}$ yang mungkin masih tertinggal, lalu dikeringkan dalam oven pada suhu $80{ }^{\circ} \mathrm{C}$ untuk menghilangkan air yang terdapat pada residu kitosan. Rendemen kitosan yang dihasilkan dari kitin melalui reaksi deasetilasi ini adalah sebesar 38,59\% atau sebanyak 10,72 gr. Pada penelitian dengan bahan cangkang udang diperoleh $32 \%$ rendemen (Lestari, 2011) Rendemen yang dihasilkan pada setiap tahapan proses pada pembuatan kitosan dari limbah cangkang kepiting sebagaimana dapat dilihat pada Tabel 1.

\section{Hasil Analisa Karakteristik Kitosan}

Kitosan yang diperoleh dari deasetilasi kitin dianalisa menggunakan spektrofotometer Fourier Transform Infra Red (FTIR). Spektroskopi inframerah merupakan suatu metode untuk mendeteksi gugus fungsional, mengidentifikasi senyawa dan menganalisis campuran (Day, RA, 2002). Dari hasil analisa karakteristik kitosan yang telah dilakukan didapatkan hasil sebagaimana ditunjukkan pada Gambar 1. Tujuan dari analisa karakteristik kitosan ini yaitu untuk mengetahui transformasi kitin menjadi kitosan dengan melihat dari gugus fungsi utamanya serta membandingkan dengan 
spektrum kitosan dari literatur. Berdasarkan Gambar 1 tersebut dapat ditentukan gugus fungsi yang terbentuk seperti yang dapat dilihat pada yang terbaca berdasarkan bilangan gelombang Tabel 2.

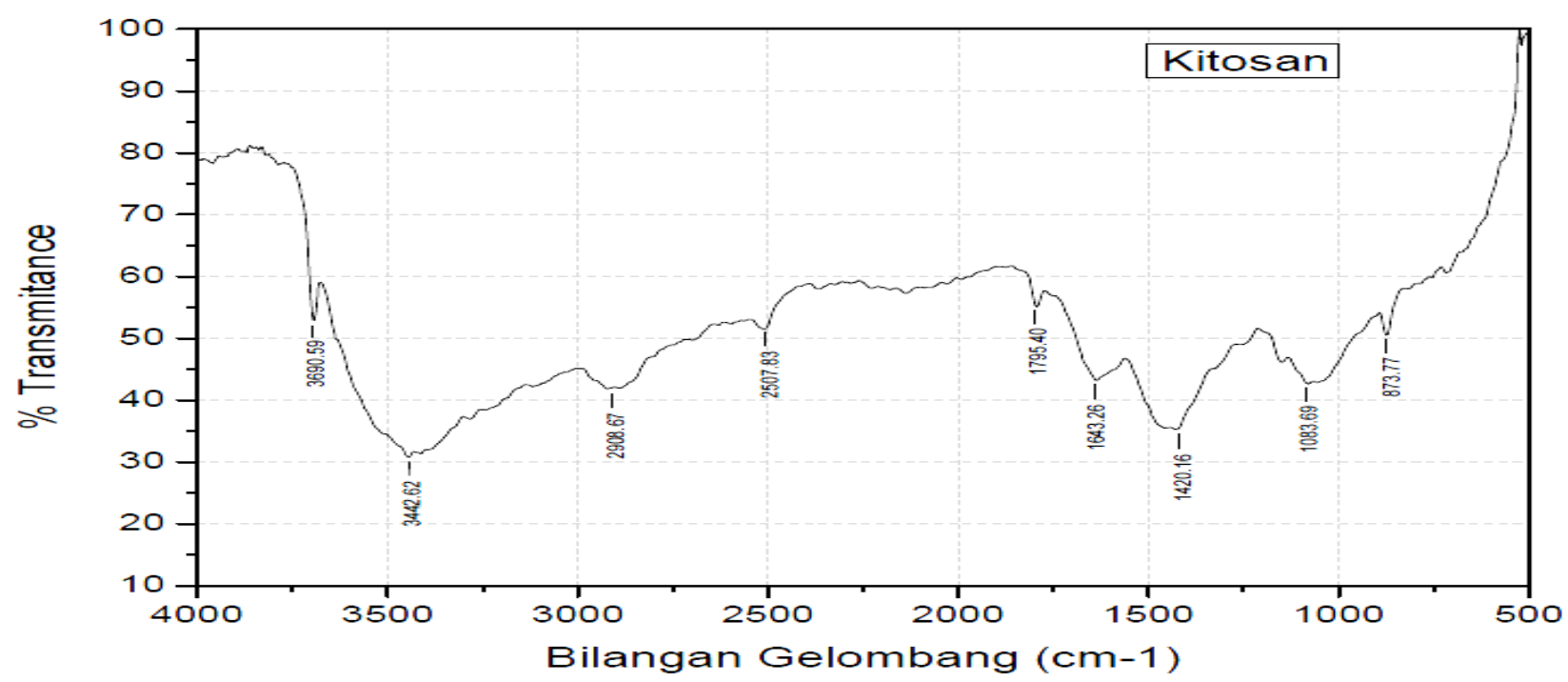

a.

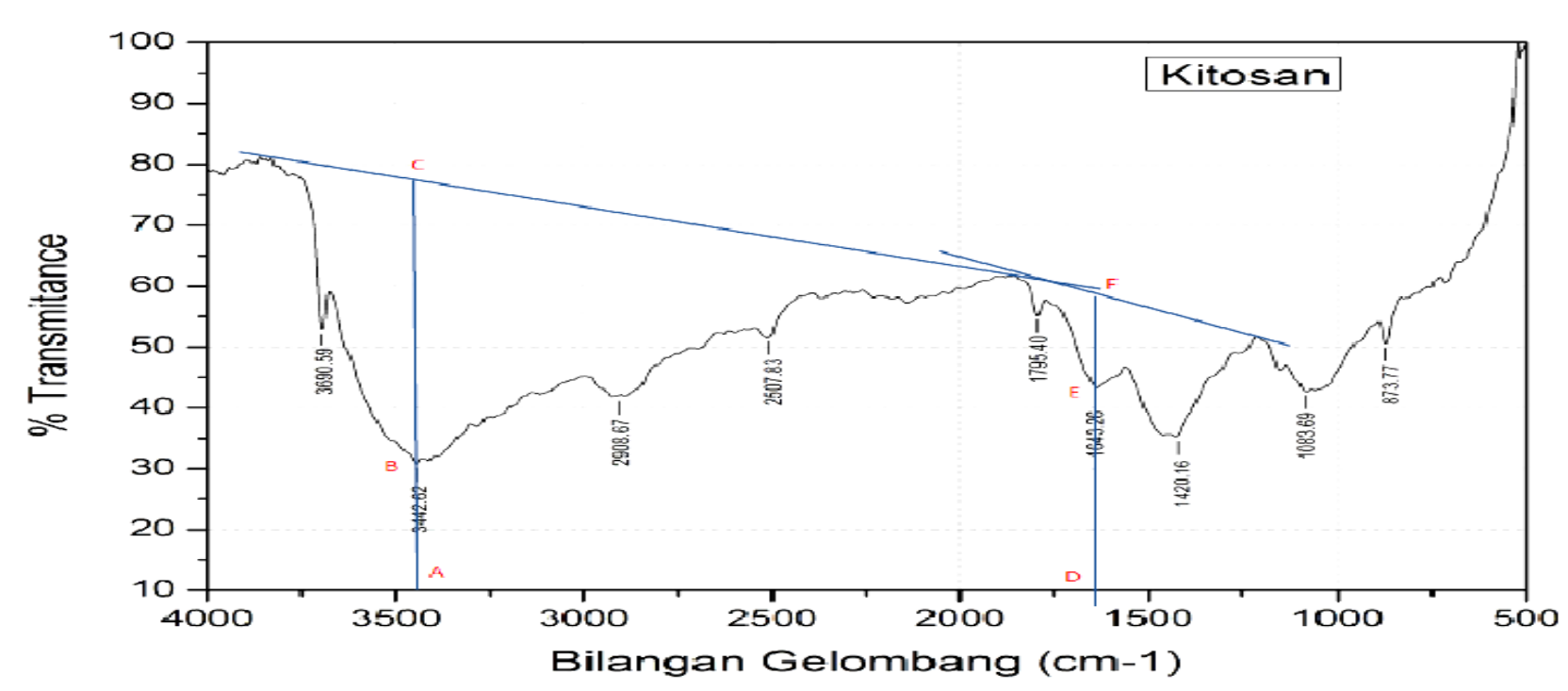

b.

Gambar 1. Karakterisasi Kitosan Berdasarkan FTIR

a. Spektrum FTIR Kitosan b. Penentuan derajat Deasetilasi Kitosan dengan Metode

Tabel 1. Rendemen Tiap Tahapan Proses Pembuatan Kitosan

\begin{tabular}{crrr}
\hline Tahapan Proses Pembuatan Kitosan & Berat Sampel & Rendemen \\
\hline Persiapan Sampel & 75,00 gram & & - \\
Tahap Demineralisasi & 29,67 gram & $39,56 \%$ & \\
Tahap Deproteinasi & 27,78 gram & $93,63 \%$ \\
Deasetilasi Kitin Menjadi Kitosan & 10,72 gram & $38,59 \%$ \\
\hline
\end{tabular}


Tabel 2. Hasil Analisa Bilangan Gelombang $\left(\mathrm{cm}^{-1}\right)$ terhadap Gugus Fungsi Kitosan

\begin{tabular}{ccr}
\hline \multirow{2}{*}{ Gugus Fungsi } & \multicolumn{2}{c}{ Bilangan gelombang $\left(\mathbf{c m}^{\mathbf{- 1}}\right)$} \\
\cline { 2 - 3 } & Literatur $*)$ & Hasil Percobaan \\
\hline $\mathrm{O}-\mathrm{H}$ & $3645-3200$ & 3442,62 \\
$\mathrm{C}=\mathrm{O}$ & $1630-1700$ & 1643,26 \\
\hline
\end{tabular}

*Sumber : Silverstein, 2005

Hasil analisa gugus fungsi kitosan menunjukkan puncak serapan pada daerah bilangan gelombang $\left(\mathrm{cm}^{-1}\right)$ : 3442,62 yang merupakan puncak serapan khas dari vibrasi O-H. Serapan pada daerah bilangan gelombang $\left(\mathrm{cm}^{-1}\right): 1643,26$ adalah serapan khas dari vibrasi gugus karbonil $(\mathrm{C}=\mathrm{O})$ sebagai serapan pita amida I (Tabel 2). Dimana dari gugus tersebut dapat dihitung kualitas kitosan dengan menghitung derajat deasetilasi kitosan. Derajat deasetilasi kitosan adalah suatu parameter mutu kitosan yang menunjukkan persentase gugus asetil yang dapat dihilangkan dari rendemen kitin maupun kitosan. Perbedaan kitin dan kitosan terletak pada perbandingan gugus amina $\left(-\mathrm{NH}_{2}\right)$ dengan gugus asetil $\left(-\mathrm{NHCOCH}_{3}\right)$ yang disebut derajat deasetilasi. Menurut Thate (2004) diacu dalam Basuki dan Sanjaya (2009), disebutkan bahwa kitosan memiliki derajat deasetilasi lebih dari $70 \%$, sedangkan kitin memiliki derajat deasetilasi kurang dari $70 \%$. Penentuan derajat deasetilasi menggunakan metode base line terhadap hasil analisa kitosan dengan menggunakan spektrofotometer Fourier Transform Infra Red (FTIR). Berdasarkan analisa FTIR tersebut dapat diketahui bahwa pajang $\mathrm{AC}=9,6 \mathrm{~cm}$, panjang $\mathrm{AB}=3 \mathrm{~cm}$, panjang $\mathrm{DF}=7 \mathrm{~cm}$ dan panjang $\mathrm{DE}=4,7 \mathrm{~cm}$. Nilai absorbansi dapat dihitung dengan menggunakan rumus:

$\mathrm{A}=\log \frac{\mathrm{P} 0}{\mathrm{P}} \quad \ldots(1)$

Dimana:

Po $=\%$ transmitasi pada garis dasar

$\mathrm{P} \quad=\%$ transmitasi pada puncak minimum
Sehingga

$$
\begin{aligned}
& \mathrm{A}_{3442,62}=\log \frac{A C}{A B} \quad \text { sedangkan } \quad \mathrm{A}_{1643,26}=\log \frac{D F}{D E} \\
& \begin{array}{ll}
=0,50515 & =0,17300
\end{array} \\
& \mathrm{DD}=\left|1-\left(\frac{\mathrm{A}_{1643,26}}{\mathrm{~A}_{3442,62}} \times \frac{1}{1,33}\right)\right| \times 100 \% \quad \ldots \text { (2) }
\end{aligned}
$$

Keterangan :

$\mathrm{A}_{3442,62}=$ nilai absorbansi pada $3442,62 \mathrm{~cm}^{-1}$

$\mathrm{A}_{1643,26}=$ nilai absorbansi pada $1643,26 \mathrm{~cm}^{-1}$ (serapan gugus hidroksil)

$1,33=$ perbandingan $\mathrm{A}_{1643,26}$ dengan $\mathrm{A}_{3442,62}$
pada derajat deasetilasi $100 \%$

Hasil perhitungan dengan rumus diatas diperoleh derajat deasetilasi kitosan $=74,25 \%$. Dengan derajat deasetilasi lebih dari $70 \%$, maka menurut Thate (2004) dalam Basuki dan Sanjaya (2009), sampel ini dapat disimpulkan sebagai kitosan. Semakin tinggi derajat deasetilasi kitosan, maka gugus asetil kitosan semakin rendah, sehingga interaksi antar ion dan ikatan hidrogennya semakin kuat (Knorr, 1991 diacu dalam Pasaribu, 2010). Sintesis kitosan dari kitin adalah dengan pemutusan ikatan antara gugus asetil kitin dengan atom nitrogen kitin (deasetilasi) sehingga berubah menjadi gugus amina $\left(\mathrm{NH}_{2}\right)$. Pelepasan gugus asetil menjadi amina pada kitosan inilah yang menyebabkan kitosan bermuatan positif. Karena kitosan mengandung gugus amina dalam rantai kabonnya dan bermuatan positif sehingga menyebabkan molekul tersebut bersifat resisten terhadap stress mekanik. Gugus amina ini dapat mengikat partikel-partikel koloid yang pada umumnya hampir semua partikel koloid didalam perairan bermuatan negatif, dimana muatan itu 
cenderung menghasilkan gaya tolak menolak antar partikel koloid yang bermuatan sama dan merupakan sebab utama terjadinya stabilitas koloid, sehingga kitosan sebagai koagulan mampu untuk mendestabilisasikan partikelpartikel di dalam perairan dan membentuk flokflok yang lebih besar sehingga dapat mengendap. Deasetilasi kitosan secara bertahap akan menghasilkan DD yang lebih baik daripada secara kontinyu dengan total waktu yang sama, sebagaimana penelitian (2009) dengan kitosan dari cangkang udang menghasilkan DD 76,48 pada satu tahap dan $84,16 \%$ pada tiga tahap namun tidak terjadi depolimerisasi (berat molekul tetap), pada penelitian (Hekwanto, 2006) diperoleh DD 85,61\% dengan deasetilasi 5 tahap dengan masing masing tahap 1 jam.

\section{Percobaan Jar-test}

Karakteristik awal dari limbah cair sarung tenun Samarinda adalah $232 \mathrm{mg} / \mathrm{L}$ untuk TSS dan $173,77 \mathrm{mg} / \mathrm{L}$ untuk warna. Dalam percobaan jartest yang telah dilakukan dengan menggunakan koagulan kitosan dari limbah cangkang kepiting, koagulan dilarutkan dalam asam asetat $(\mathrm{CH} 3 \mathrm{COOH}) 2 \%$ sampai diperoleh larutan kitosan dengan kadar $1 \%$. Penggunaan pelarut asam asetat sebagimana penelitian (Zemmouri, H., 2012) bahwa kitosan bersifat hidrofilik polimer mempunyai gugus amina sebagai polikationik, pengkelat dan pembentuk dispersi dalam larutan asam asetat organik maupun inorganik. Pada penyesuaian $\mathrm{pH}$ terhadap penentuan dosis optimum ditambahkan dosis kapur $2 \%$ pada masing-masing sampel limbah cair hingga $\mathrm{pH}$ pada sampel limbah cair 1 menjadi 7,15. Setelah dilakukan jar-test pada semua variasi dosis, dilakukan pengamatan berdasarkan perubahan warna, flok yang terbentuk dan $\mathrm{pH}$ yang bertujuan untuk dapat menentukan 6 dosis terbaik dari 12 variasi dosis. Dari hasil pengamatan maka diperoleh dosis terbaik yaitu $35 \mathrm{ml}, 40 \mathrm{ml}, 45 \mathrm{ml}, 50 \mathrm{ml}, 55 \mathrm{ml}$ dan $60 \mathrm{ml}$ yang kemudian akan dilakukan analisa volume lumpur dari flok yang terbentuk dengan menggunakan imhoff cone atau kerucut imhoff.

\section{Analisa Volume Lumpur yang Terbentuk}

Pada penelitian ini dilakukan analisa volume lumpur yang terbentuk dari 6 dosis terbaik setelah dilakukan jar-test. Dalam analisa penentuan volume lumpur digunakan imhoff cone atau kerucut imhoff dengan waktu pengendapan selama 60 menit dengan variasi waktu pengamatan yaitu 10 menit, 20 menit, 30 menit, 40 menit, 50 menit dan 60 menit, dengan satuan ml per volume sampel. Analisa tersebut dapat dilihat pada Gambar 2.

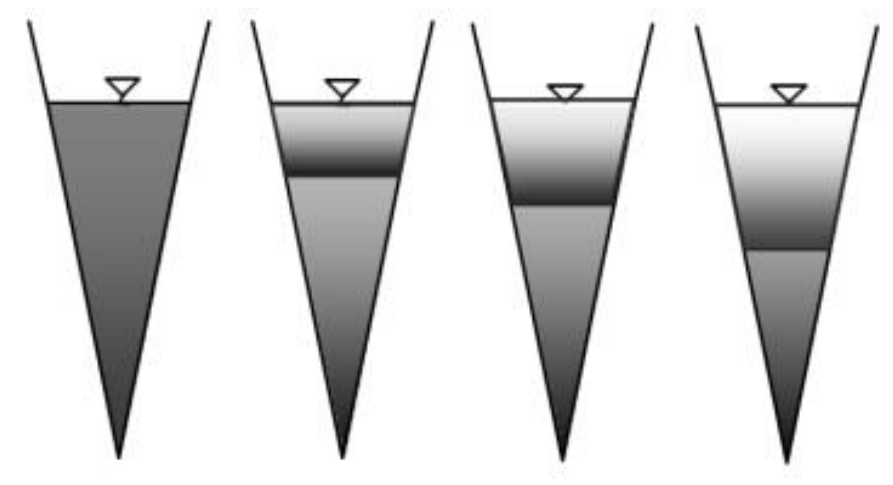

(a)

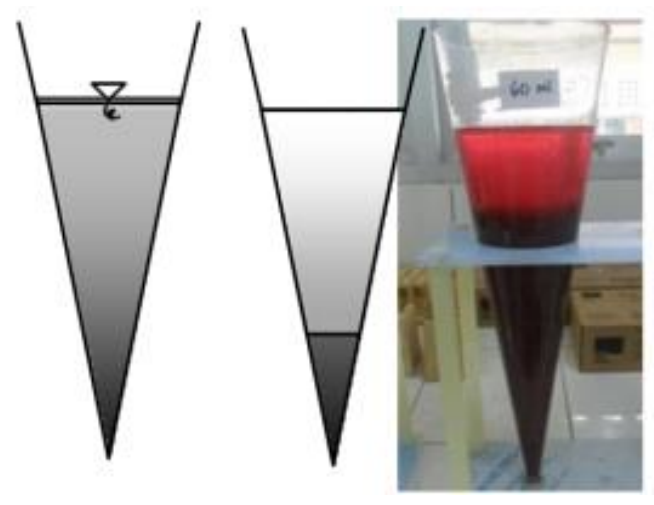

(b)

Gambar 2. Pengendapan dengan Kerucut Imhoff

a. Tahapan pengamatan flok

b. Contoh pengamatan flok pada menit ke 10 
Tabel 3. Hasil Analisa Volume Flok pada Sampel Limbah Cair

\begin{tabular}{crrrrrr}
\hline $\begin{array}{c}\text { Dosis Koagulan } \\
\text { Kitosan } \\
(\mathbf{m l})\end{array}$ & $\begin{array}{c}\mathbf{1 0} \text { menit } \\
(\mathbf{m l} / \mathbf{L})\end{array}$ & $\begin{array}{c}\mathbf{2 0} \text { menit } \\
(\mathbf{m l} / \mathbf{L})\end{array}$ & $\begin{array}{c}\mathbf{3 0} \text { menit } \\
(\mathbf{m l} / \mathbf{L})\end{array}$ & $\begin{array}{c}\mathbf{4 0} \text { menit } \\
(\mathbf{m l} / \mathbf{L})\end{array}$ & $\begin{array}{c}\mathbf{5 0} \text { menit } \\
(\mathbf{m l} / \mathbf{L})\end{array}$ & $\begin{array}{c}\mathbf{6 0} \mathbf{m e n i t} \\
(\mathbf{m l} / \mathbf{L})\end{array}$ \\
\hline 35 & 450 & 350 & 320 & 305 & 280 & 270 \\
40 & 530 & 390 & 340 & 325 & 315 & 300 \\
45 & 550 & 390 & 340 & 330 & 310 & 285 \\
50 & 525 & 400 & 350 & 320 & 300 & 285 \\
55 & 550 & 440 & 380 & 350 & 325 & 305 \\
60 & 630 & 460 & 400 & 310 & 340 & 320 \\
\hline
\end{tabular}

Tabel 4. Hasil Analisa Efisiensi Penurunan Warna dan TSS

\begin{tabular}{|c|c|c|c|c|c|c|}
\hline $\begin{array}{l}\text { Dosis } \\
\text { Koagulan } \\
\text { Kitosan } \\
(\mathrm{ml})\end{array}$ & $\begin{array}{l}\text { Analisa } \\
\text { Awal } \\
\text { Warna } \\
\text { (PtCo) }\end{array}$ & $\begin{array}{c}\text { Analisa Warna } \\
\text { Setelah Perlakuan } \\
\text { (PtCo) }\end{array}$ & $\begin{array}{c}\text { Efisiensi } \\
\text { Penurunan } \\
\text { Warna }(\%)\end{array}$ & $\begin{array}{c}\text { Analisa } \\
\text { Awal TSS } \\
(\mathrm{mg} / \mathrm{L})\end{array}$ & $\begin{array}{c}\text { Analisa TSS } \\
\text { Setelah Perlakuan } \\
(\mathrm{mg} / \mathrm{L})\end{array}$ & $\begin{array}{c}\text { Efisiensi } \\
\text { Penurunan } \\
\text { TSS }(\%)\end{array}$ \\
\hline 35 & & 112,10 & 35,49 & & 26 & 88,79 \\
\hline 40 & & 115,54 & 33,51 & & 23 & 90,09 \\
\hline 45 & 173,77 & 112,53 & 35,24 & 232 & 29 & 87,50 \\
\hline 50 & & 110,37 & 36,49 & & 24 & 89,65 \\
\hline 55 & & 108,08 & 37,80 & & 15 & 93,53 \\
\hline 60 & & 100,62 & 42,09 & & 26 & 88,79 \\
\hline
\end{tabular}

Analisa diatas menunjukkan jumlah volume endapan lumpur yang terbentuk dari flok-flok partikel. Hasil dari analisa volume lumpur yang terbentuk setelah proses jar-test dapat dilihat pada tabel 3. Berdasarkan hasil pengamatan setelah dilakukan jar-test dengan penambahan koagulan kitosan, pada menit ke 10 mulai terjadi pemisahan flok/lumpur dengan limbah cair yang ditandai perubahan kepekatan warna pada sampel (Gambar 2), volume lumpur yang terbentuk pada menit ke 10 pertama dihasilkan rata-rata diatas $400 \mathrm{ml} / \mathrm{L}$, untuk volume lumpur pada menit berikutnya yaitu menit ke 20, 30, 40, 50 dan 60 terjadi penurunan volume lumpur diiringi penurunan kepekatan warna pada sampel limbah cair. Penurunan volume lumpur tersebut disebabkan terjadinya proses pemadatan lumpur yang sebelumnya masih terdapat rongga-rongga yang terisi air dengan penambahan waktu terjadi pemadatan lumpur sehingga volume lumpur menurun.

\section{Pengaruh Penambahan Koagulan Kitosan terhadap Warna}

Pada parameter warna dari pengamatan fisik terjadi perubahan penurunan kadar warna pada limbah setelah dilakukan jar-test dengan menggunakan koagulan kitosan dari limbah cangkang kepiting. Menurut analisa laboratorium, kadar warna pada limbah sebelum dilakukan penambahan koagulan yaitu 173,77. Dari analisa tersebut dapat menggambarkan bahwa warna pada limbah cair tenun sarung Samarinda cukup pekat. Hal tersebut disebabkan karena dalam proses persiapan bahan baku pembuatan tenun sarung Samarinda dilakukan proses pewarnaan benang dengan menambahkan zat pewarna tekstil sehingga menyebabkan tingginya kadar warna pada limbah. Dari hasil penambahan koagulan kitosan didapatkan penurunan tertinggi yaitu $42,09 \%$. Penurunan kadar warna pada limbah cair terjadi seiring penambahan jumlah koagulan. Semakin tinggi 
dosis koagulan yang dicampurkan ke dalam limbah maka semakin turun pula kadar warna pada limbah hingga mencapai efisiensi penurunan sebesar $42,09 \%$ dengan penambahan dosis sebesar $60 \mathrm{ml}$. Hal tersebut sesuai dengan hasil penelitian Arifin, dkk., (2012), bahwa penurunan zat warna meningkat seiring dengan meningkatnya massa adsorben (kitosan) yang digunakan. Sedangkan untuk TSS menunjukkan bahwa kitosan mampu menurunkan TSS limbah cair tenun sarung Samarinda dari $232 \mathrm{mg} / \mathrm{L}$ (karakteristik awal limbah cair) menjadi $29 \mathrm{mg} / \mathrm{L}$ hingga $15 \mathrm{mg} / \mathrm{L}$ dengan efisiensi penurunan dari $87,50 \%$ hingga 93,53\%. Namun secara keseluruhan hasil analisa setelah proses koagulasi flokulasi berada di bawah baku mutu yang ditetapkan berdasarkan Keputusan Menteri Negara Lingkungan Hidup No. 51 tahun 1995 tentang Baku Mutu Limbah Cair bagi Kegiatan Industri yaitu sebesar $50 \mathrm{mg} / \mathrm{L}$. Pengaruh penambahan dosis koagulan pada penurunan kadar TSS juga mempengaruhi volume lumpur yang dihasilkan sebagaimana Tabel 3 bahwa pada dosis terendah yaitu $35 \mathrm{ml}$ dengan penurunan dosis menjadi $26 \mathrm{mg} / \mathrm{L}$ menghasilkan lumpur sebanyak $270 \mathrm{ml} / \mathrm{L}$. Sedangkan untuk dosis berikutnya yaitu $40 \mathrm{ml}$, kadar TSS mengalami penurunan lebih baik hingga $23 \mathrm{mg} / \mathrm{L}$ dan lumpur yang dihasilkan juga meningkat menjadi $300 \mathrm{ml} / \mathrm{L}$. Hal tersebut disebabkan karena koagulan kitosan ini memiliki mekanisme koagulasi dengan adsorpsi dan jembatan antar partikel sehingga gugus terionisasi aktif yang tersedia dari kitosan memungkinkan terjadinya adsorpsi kuat pada permukaan polimer. Pada konsentrasi polimer yang rendah akan terjadi adsorpsi, tetapi pembentukan jembatan ini tidak sempurna karena sebagian polimer yang tersisa dalam larutan tidak cukup untuk mengikat partikel yang lain. Sedangkan pada konsentrasi optimum bagian sisa tersebut akan terserap kedalam partikel yang berdekatan untuk membentuk jembatan antar partikel (Metcalf Eddy, 2003). Penambahan jumlah dosis koagulan hingga batas optimum menyebabkan meningkatnya pula penurunan kadar TSS yang diikuti dengan penambahan jumlah volume lumpur yang dihasilkan. Penambahan koagulan kitosan juga menyebabkan terjadinya penurunan $\mathrm{pH}$ hingga 4,75. Perubahan $\mathrm{pH}$ setelah penambahan variasi dosis koagulan kitosan pada sampel dapat dilihat pada Gambar 3.

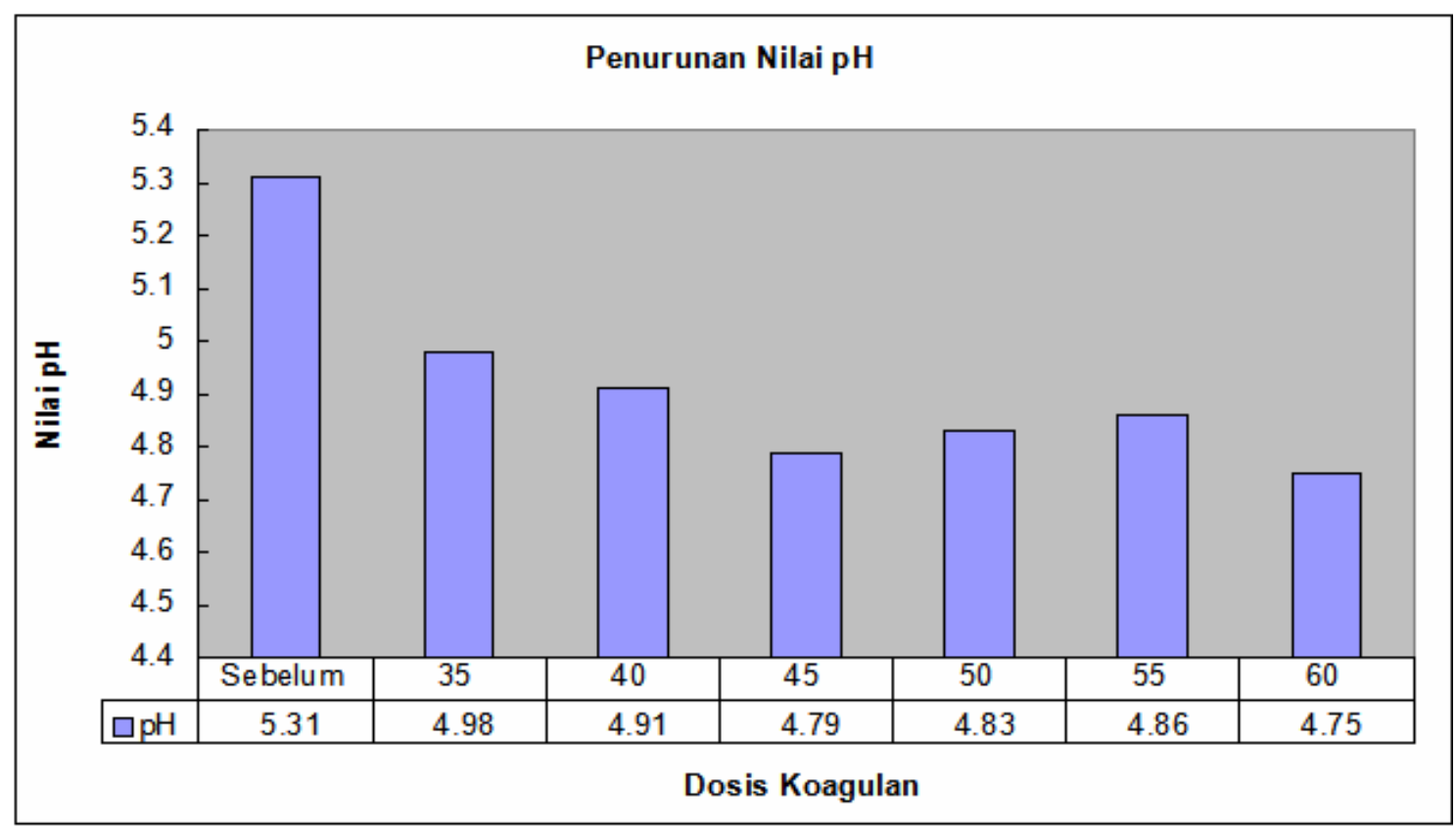

Gambar 3. Grafik Penurunan pH pada Pemberian Dosis Koagulan Kitosan 
Penambahan koagulan kitosan berpengaruh sangat signifikan pada penurunan nilai $\mathrm{pH}$ dengan dosis terkecil yaitu $35 \mathrm{ml}$ dengan nilai $\mathrm{pH}$ awal 7 (setelah dilakukan pengaturan nilai $\mathrm{pH}$ ) menjadi 4,98. Penurunan nilai $\mathrm{pH}$ ini diakibatkan oleh koagulan yang digunakan memiliki sifat asam karena kitosan dilarutkan dalam asam asetat $\left(\mathrm{CH}_{3} \mathrm{COOH}\right) 2 \%$. Penambahan koagulan berbanding lurus dengan perubahan penurunan $\mathrm{pH}$, semakin besar dosis koagulan yang ditambahkan maka penurunan $\mathrm{pH}$ akan semakin besar.

\section{KESIMPULAN DAN SARAN}

\section{Kesimpulan}

Dari hasil penelitian yang telah dilakukan, dapat diambil beberapa kesimpulan yaitu Koagulan dari limbah cangkang kepiting yang telah dibuat memiliki karakteristik yang memenuhi mutu kitosan dengan derajat deasetilasi sebesar $74,25 \%$. Penggunaan koagulan kitosan dari limbah cangkang kepiting mampu menangani limbah cair tenun sarung Samarinda efisiensi terbesar yaitu $93,53 \%$ untuk TSS dan $42,09 \%$ untuk warna. Peningkatan efisiensi removal TSS akan diikuti dengan penambahan jumlah volume lumpur yang dihasilkan. Penggunaan asam asetat sebagai pelarut akan mempengaruhi nilai $\mathrm{pH}$ limbah menjadi asam setelah proses koagulasi flokulasi yang berbanding lurus dengan dosis kitosan yang ditambahkan

\section{Saran}

Perlu dilakukan pengujian karakteristik dari lumpur yang dihasilkan untuk mengetahui apakah flok-flok yang terbentuk setelah pemberian koagulan kitosan dari limbah cangkang kepiting masih mempunyai kandungan koagulan atau adsorben. Penggunaan pelarut kitosan dengan jenis pelarut yang lain yang tidak menyebabkan penurunan $\mathrm{pH}$ yang cukup tinggi.

\section{DAFTAR PUSTAKA}

Arifin, Z., Irawan, D., Rahim, M., Ramantiya, F. 2012. Adsorpsi Zat Warna Direct Black 38 Menggunakan Kitosan Berbasis
Limbah Udang Delta Mahakam. Jurnal Sains dan Terapan Kimia, 6(1).

Basuki, B.R., Sanjaya, I.G.M. 2009. Sintesis Ikat Silang Kitosan Dengan Glutaraldehid Serta Identifikasi Gugus Fungsi dan Derajat Deasetilasinya. Jurnal Ilmu Dasar, 10(1).

Day, R.A. 2002. Analisis Kimia Kuatitatif, Erlangga. Jakarta.

Faiz, Asif,. Weaver S. Christopher., Walsh P. Michael. 1996. Air Pollution from Motor Vehicles. Washington DC.

Ginting, C. 2009. Interaksi antara peningkatan konsentrasi karbondioksida dan suhu terhadap pertumbuhan tanaman. Buletin Ilmiah INSTIPER, 16(1).

Harahap, S. 2011. Penggunaan Kitosan Dari Kulit Udang Dalam Menurunkan Kadar Total Suspended Solid (TSS) pada Limbah Cair Industri Plywood. Jurnal Akuatika, 10(1).

Herwanto, B., Santoso, E. 2006. Adsorpsi Ion Logam Berat $\mathrm{Pb}(\mathrm{II})$ pada Membran Selulosa- Khitosan Terikat Silang. Akta Kimindo, 2(1).

Ibrahim, B., Suptijah, P. Prantommy. 2009. Pemanfaatan Kitosan pada Pengolahan Limbah Cair Industri Perikanan. 12(2).

Junaidi, A.B., kartini, I., Rusdiarso, B. 2009. Chitosan Preparation With Multistage Deacetylation of Chitin and Investigation of Its Physicochemical Properties. Indo. J. Chem, 9(3).

Junaidi, Hatmanto, B.P.D. 2006. Analisis Teknologi Pengolahan Limbah Cair Pada Industri Tekstil (Studi Kasus PT. Iskandar Indah Printing Textile Surakarta). Jurnal Presipitasi, 1(1).

Lestari, I., Snova, A. 2011. Penyerapan Logam Berat Cadmium (Cd) Menggunakan Kitosan Hasil Transformasi Khitin Dari Kulit Udang (Penaeus sp). Jurnal 
Penelitian Universitas Jambi Seri Sains, 13(1).

Metcalf and Eddy. 2003. Wastewater Engineering Treatment and Reuse. $4^{\text {th }}$ ed. McGraw-Hill, New York.

Puspawati, N.M. Simpen, I.N. 2010. Optimasi Deasetilasi Khitin dari Kulit Udang dan Cangkag Kepiting Limbah Restoran Seafood Menjadi Khitosan Melalui Variasi Konsentrasi NaOH. Jurnal Kimia, 4(2).

Ritung, S., Wahyunto, Agus, F., dan Hidayat, H. 2007. Panduan Evaluasi Kesesuaian Lahan dengan Contoh Peta Arahan Penggunaan Lahan Kabupaten Aceh Barat. Balai Penelitian Tanah dan World Argoforestry Centre (ICRAF).

Sanjaya, I., Yuanita, L. 2007. Adsorpsi Pb (II) oleh Kitosan Hasil Isolasi Kitin Cangkang Kepiting Bakau. Jurnal Ilmu Dasar, 8(1).

Samar, M.M., El-Kalyoubi, M., H., Khalaf, M.M., Abd El Razik, M.M. 2013. Physicochemical, Functional, Antioxidant and Antibacterial Propertis of Chitosan Extracted from Shrimp Wsates by Microwave Technique. Jurnal Annals of Agricultural Science, 58(1).

Savitri, E., Soeseno, N., AdiRTO, t. 2010. Sintesis Kitosan, Poli (2-amino-2-deoksiD-Glukosa) Skala Project dari Limbah Kulit Udang Sebagai Bahan Baku Alternatif Pembuatan Biopolimer. Prosiding Seminar Nasional Teknik Kimia. ISSN 1693 - 4393.

Silverstein, R.M. 2005. Spectrometric Identifikation of Organic Compound $7^{\text {th }}$. John Wiley and Sons Inc. State University of New York.

Srijanto, B., Paryanto, I., Masduki, Purwatiningsih. 2006. Pengaruh Derajat deasetilasi Bahan Baku Pada Depolimerisasi Kitosan. Akta Kimindo, 1(2).

Zemmouri, H., Drouiche, M., Sayeh, A., Lounici, H., Mameri, N. 2012. Coagulation Flocculation Test of Keddara's Water Dam Using Chitosan and Sulfate Aluminium. Journal Procedia Engineering, 33(1). 